\title{
Peningkatan Kemampuan Pemecahan Masalah dan Keaktifan Belajar Siswa SMA melalui Means-Ends Analysis
}

\author{
Komang Ayu Nadya Suhita Lestari ${ }^{*}$, Gusti Ayu Mahayukti², Ni Made Sri \\ Mertasari $^{3}$ \\ 1,2,3Program Studi Pendidikan Matematika, Universitas Pendidikan Ganesha, Singaraja, \\ Indonesia; ${ }^{1 *}$ nadyalestari82@gmail.com; 2gustiayumahayukti@gmail.com; \\ 3srimertasarinimade@yahoo.co.id.
}

Info Artikel: Dikirim: 6 Mei 2020; Direvisi: 5 Juni 2020; Diterima: 11 September 2020

Cara sitasi: Lestari, K. A. N. S., Mahayukti, G. A., \& Mertasari, N. M. S. (2020). Peningkatan Kemampuan Pemecahan Masalah dan Keaktifan Belajar Siswa SMA Melalui Means-Ends Analysis. JNPM (Jurnal Nasional Pendidikan Matematika), 4(2), 263-278.

\begin{abstract}
Abstrak. Penelitian ini bertujuan untuk meningkatkan kemampuan pemecahan masalah dan keaktifan belajar siswa melalui penerapan model pembelajaran MeansEnds Analysis (MEA) pada materi Fungsi. Penelitian ini merupakan penelitian tindakan kelas meliputi tiga siklus dengan empat tahapan, yaitu perencanaan, pelaksanaan, observasi, dan refleksi. Subjek penelitian adalah siswa kelas X SMA Negeri di Singaraja yang berjumlah 37 orang. Data dikumpulkan melalui tes kemampuan pemecahan masalah dan lembar observasi keaktifan belajar. Hasil menunjukkan bahwa kemampuan pemecahan masalah pada setiap siklusnya mengalami peningkatan. Siklus I, rata-rata tes kemampuan pemecahan masalah sebesar 58,78; pada siklus II sebesar 69,05; dan pada siklus III sebesar 76,82. Keaktifan belajar juga mengalami peningkatan, persentase pada siklus I sebesar 52,87\% dengan kriteria cukup, siklus II sebesar 65,26\% dengan kriteria baik, dan siklus III sebesar $78,38 \%$ dengan kriteria baik. Sehingga dapat dikatakan bahwa penerapan model pembelajaran MEA dapat meningkatkan kemampuan pemecahan masalah dan keaktifan belajar siswa.
\end{abstract}

Kata Kunci: Pemecahan Masalah, Keaktifan Belajar, Means-Ends Analysis.

Abstract. This study aims to improve students' problem-solving abilities and to learn activeness by applying the Means-Ends Analysis (MEA) learning model on the function material. This research is a classroom action research consisting of three cycles with four stages, namely planning, implementing, observing, and reflecting. The research subjects were 37 students of class X, one of a State High School in Singaraja. Data were collected through tests of problem-solving abilities and observation sheets of learning activeness. The results show that the problem-solving ability in each cycle has increased. Cycle I, the average problem-solving ability test was 58.78; in cycle II amounted to 69.05, and in the third cycle of 76.82. Learning activeness also increased, the percentage in cycle I was $52.87 \%$ with sufficient criteria, 
cycle II was $65.26 \%$ with good criteria, and cycle III was $78.38 \%$ with good criteria. So it can be said that applying the MEA learning model can improve problem-solving abilities and student learning activeness.

Keywords: Problem solving ability, learning activity, Means-Ends Analysis.

\section{Pendahuluan}

Pendidikan merupakan salah satu aspek penting dalam pengembangan kemajuan suatu bangsa dan negara. Salah satu proses pendidikan adalah proses belajar mengajar yang bertujuan untuk meningkatkan taraf pendidikan bangsa. Hal tersebut sejalan dengan dunia kerja yang sangat membutuhkan Sumber Daya Manusia (SDM) dengan kompetensi unggul dan aktif. Menurut Suherman (2003), matematika merupakan salah satu ilmu pengetahuan yang diperoleh dengan bernalar. Matematika merupakan mata pelajaran dengan tingkat kesulitan yang cenderung lebih tinggi dibandingkan dengan mata pelajaran yang lain (Varma \& Schwartz, 2011), sehingga demikian banyak siswa yang ragu terhadap kemampuan dirinya dalam menyelesaikan soalsoal matematika, hal tersebut menyebabkan banyak siswa yang tidak menyukainya, bahkan ada yang menghindarinya (Harkness \& Noblitt, 2017; Sinaga, 2018). Jening dan Dunne (Rahmawati, 2013) menyatakan bahwa masih terdapat banyak siswa yang mengalami kesulitan untuk mengaplikasikan matematika ke dalam kehidupan sehari-hari yang berdampak pada tingkat pemahaman siswa dalam mempelajari matematika.

Rendahnya kemampuan siswa dalam menerjemahkan permasalahan berupa soal cerita ke dalam bentuk kalimat matematika, membuat siswa menjadi kurang tertarik untuk memecahkan permasalahan tersebut. Tetapi dalam kehidupan sehari-hari sangat diperlukannya kemampuan dalam memecahkan suatu masalah, salah satunya masalah matematika. Pemecahan masalah juga salah satu kemampuan yang harus dikuasai siswa dalam pembelajaran matematika. Hal ini sejalan dengan Permendiknas No 22 Tahun 2006 yang menyatakan bahwa pelajaran matematika bertujuan agar peserta didik memiliki kemampuan kemampuan memahami masalah, merancang model matematika, menyelesaikan model, dan menafsirkan solusi yang diperoleh. Kemampuan pemecahan masalah matematika juga sangat diperlukan terutama dalam menghadapi permasalahan yang sama dan membutuhkan solusi yang berkelanjutan (Chaudhry \& Rasool, 2012).

Menurut Chavez (2007), pemecahan masalah dapat didefinisikan sebagai proses untuk merumuskan jawaban atau pendekatan baru yang melibatkan lebih dari penerapan sederhana dari aturan yang dipelajari sebelumnya. Kebanyakan masalah yang dihadapi saat ini adalah kategori non rutin, yakni 
masalah yang penyelesaiannya membutuhkan keterampilan prosedural, tetapi juga keterampilan dalam memutuskan penyelesaian masalah (Laterell, 2013). Selain itu, Csapó \& Funke (2017) menyatakan bahwa kemampuan pemecahan masalah merupakan kemampuan seseorang dalam bereksplorasi dan memunculkan strategi yang kreatif untuk memperoleh pengetahuan sehingga menemukan solusinya. Tetapi pada kenyataannya, sangat sulit bagi siswa untuk meningkatkan kemampuan pemecahan masalah. Hal tersebut didukung oleh Malalina \& Kesumawati (2014) yang menyatakan bahwa siswa belajar sesuai contoh yang diberikan guru, sehingga pada saat diberikan soal non rutin (masalah matematis), siswa mengalami kesalahan dalam menyelesaikannya. Menurut Polya (1957) terdapat empat tahapan pemecahan masalah, yaitu memahami masalah, membuat rencana, melakukan penyelesaian masalah, dan melihat kembali.

Kemampuan pemecahan matematika siswa kelas X MIPA 2 SMA Negeri 2 Singaraja masih rendah dan perlu untuk ditingkatkan. Hal ini didukung oleh hasil ulangan harian siswa pada semester ganjil tahun ajaran 2019/2020 yang masih belum sepenuhnya memenuhi kriteria ketuntasan minimal yaitu 70 . Materi yang diujikan pada ulangan harian tersebut adalah Sistem Persamaan Linear Tiga Variabel (SPLTV). Soal ulangan harian siswa ini berbentuk soal cerita yang dimana cara penyelesaiannya menggunakan langkah-langkah pemecahan masalah. Sehingga dengan melihat hasilnya, peneliti menyakini bahwa kemampuan pemecahan masalah siswa masih tergolong rendah. Diperoleh hasil rata-rata nilai ulangan harian siswa adalah 49,73 dengan persentase ketuntasan belajar klasikal yakni mencapai 27,03\%. Berikut ini hasil jawaban hasil ulangan harian dari salah satu siswa pada Gambar 1.

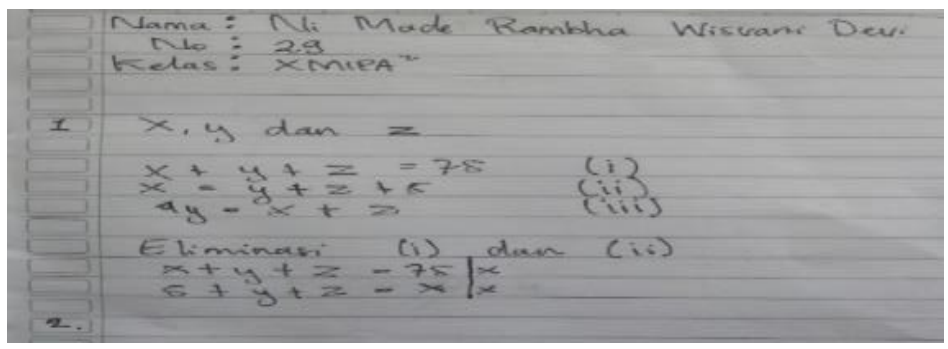

Gambar 1. Hasil Jawaban Ulangan Harian Siswa

Gambar 1 menunjukkan bahwa bagian yang dirasa paling sulit oleh siswa adalah bagian memahami masalah. Karena sebagian besar siswa masih belum mampu menuliskan informasi apa yang diketahui dan yang ditanyakan pada soal. Memahami masalah adalah bagian terpenting dari proses pemecahan masalah, karena dengan siswa memahami masalah maka permasalahan yang dihadapi dengan mudah diselesaikan (Özreçberoğlu \& Çağanağa, 2018). Hal- 
hal yang dapat dilaksanakan ketika memahami masalah adalah dengan cara mengetahui dan menentukan apa yang diketahui serta apa yang ditanyakan pada soal. Tahap merencanakan solusi adalah dengan cara menentukan strategi solusi dari hal yang diketahui dan ditanya pada soal yang sekiranya cocok digunakan dalam menyelesaikan permasalahan. Kemudian dilanjutkan dengan melaksanakan rencana solusi dan memeriksa kembali (Polya, 1957).

Peneliti menemukan permasalahan lain yang dialami sebagian besar siswa pada kegiatan observasi, seperti tidak memperhatikan guru saat proses pembelajaran, mengerjakan hal-hal lain diluar materi pelajaran, siswa juga lebih cenderung diam dan tidak berani dalam mengemukakan pendapat. Selain itu, peneliti mewawancarai beberapa siswa, siswa mengatakan bahwa alasannya adalah kurangnya minat siswa dalam mempelajari matematika dan memecahkan permasalahan yang disajikan oleh guru. Hal itu dikarenakan rendahnya kemampuan pemecahan masalah yang dialami oleh sebagian besar siswa mengakibatkan menurunnya keaktifan belajar siswa. Keaktifan siswa dalam kegiatan pembelajaran adalah untuk mengkontruksi pengetahuannya sendiri. Sehingga siswa aktif membangun pemahaman atas permasalahan atau segala sesuatu yang mereka hadapi dalam setiap proses pembelajaran. Menurut Syah (2008) keaktifan siswa dipengaruhi oleh beberapa faktor, yaitu: faktor internal, faktor eksternal, dan pendekatan belajar. Dalam hal ini, peran guru juga sangat mempengaruhi dalam keaktifan belajar siswa (Usman, 2009).

Berdasarkan persoalan di atas, dibutuhkan inovasi dari pembelajaran di kelas. Salah satunya adalah dengan menerapkan model pembelajaran yang sintaksnya dapat membantu siswa dalam meningkatkan kemampuan pemecahan masalah dan keaktifan belajarnya. Model pembelajaran yang memungkinkan bagi peneliti adalah model pembelajaran Means-Ends Analysis (MEA). Menurut Suherman (2008) dan Huda (2014) model pembelajaran MEA merupakan model pembelajaran variasi antara metode pemecahan masalah dengan sintaks yang menyajikan materi dengan pendekatan pemecahan masalah berbasis heuristic, mengelaborasi menjadi sub-sub masalah yang lebih sederhana, mengidentifikasi perbedaan, menyusun sub-sub masalahnya sehingga terjadi konektivitas, dan memilih strategi solusi. Sehingga model pembelajaran MEA ini merupakan suatu pengembangan dari jenis pemecahan masalah dengan penyederhanaan masalah dalam mencari cara yang efektif untuk memecahkan permasalahan matematika. Selain itu model pembelajaran MEA ini sangat efektif dalam meningkatkan partisipasi siswa, karena dalam pelaksanaannya mengharuskan siswa berdiskusi kelompok yang terdiri dari 4-5 orang siswa yaitu siswa akan lebih aktif dan lebih mudah 
dalam mengeluarkan ide. Pada tahap mengindentifikasi perbedaan dan memilin strategi solusi, siswa akan lebih aktif berdiskusi dengan temannya, bertanya dengan teman ataupun guru ketika ada kesulitan.

Penelitian Saraswati, Kristin, \& Anugraheni (2018) juga menunjukkan bahwa untuk meningkatkan kemampuan pemecahan masalah matematika dengan model pembelajaran MEA di SD kelas 5. Peneliti mencoba membuat pembaruan dengan menerapkan model pembelajaran MEA pada siswa kelas $X$ MIPA 2 SMA. Sehubungan dengan hal tersebut, penulis melakukan penelitian yang bertujuan untuk meningkatkan kemampuan pemecahan masalah matematika dan keaktifan belajar siswa kelas X MIPA 2 SMA Negeri 2 Singaraja melalui penerapan model pembelajaran MEA. Tujuan dari penelitian ini adalah untuk mengetahui peningkatan kemampuan pemecahan masalah matematika dan keaktifan belajar siswa melalui model pembelajaran MEA.

\section{Metode}

Penelitian ini merupakan penelitian tindakan kelas dengan subjek penelitian adalah siswa kelas X MIPA 2 SMA Negeri 2 Singaraja yang berjumlah 37 orang. Permasalahan bermula dari hasil ulangan harian siswa pada semester ganjil tahun ajaran 2019/2020. Berikut dapat dicermati pada Tabel 1.

\begin{tabular}{ccccc}
\multicolumn{4}{c}{ Tabel 1. Data Nilai Ulangan Harian Siswa } \\
\hline $\begin{array}{c}\text { Nilai } \\
\text { Tertinggi }\end{array}$ & $\begin{array}{c}\text { Nilai } \\
\text { Terendah }\end{array}$ & $\begin{array}{c}\text { Rata-rata } \\
\text { Nilai }\end{array}$ & $\begin{array}{c}\text { Banyak Siswa yang } \\
\text { Belum Tuntas }\end{array}$ & $\begin{array}{c}\text { Persentase } \\
\text { Ketuntasan Belajar } \\
\text { Klasikal }\end{array}$ \\
\hline 83,3 & 23,3 & 49,73 & 27 & $27,03 \%$ \\
\hline
\end{tabular}

Tabel 1 menunjukkan bahwa persentase ketuntasan belajar klasikal siswa masih rendah, sehingga diperlukan tindakan untuk memperbaiki hasil belajar siswa.

Penelitian ini dilaksanakan pada awal semester genap tahun ajaran 2019/2020 yang berlangsung dari bulan Januari sampai Maret tahun 2020. Penelitian ini terdiri atas 3 siklus, dengan 4 kali pertemuan setiap siklusnya. Adapun jadwal pelaksanaan tindakan dengan pembagian materinya disajikan pada Tabel 2.

Tabel 2. Jadwal Pelaksanaan Penelitian

\begin{tabular}{cccl}
\hline No & Siklus & Tanggal Pelaksanaan & \multicolumn{1}{c}{ Materi Pelajaran } \\
\hline 1 & I & 13-27 Januari 2020 & Notasi, Domain, Range, dan Grafik Suatu \\
& & Fungsi & \\
2 & II & $30-10$ Februari 2020 & Operasi Aljabar dan Komposisi Fungsi \\
\hline
\end{tabular}




3 III $\quad$ 13-6 Maret 2020 $\quad$ Fungsi Invers dan Invers Komposisi Fungsi

Pada Tabel 2 terlihat bahwa dalam jadwal pelaksanaan penelitian ini berlangsung selama 3 siklus dimulai pada tanggal 13 Januari 2020 sampai dengan 6 Maret 2020 dengan materi pelajaran yang dipilih yaitu Fungsi.

Data hasil kemampuan pemecahan masalah diperoleh dengan menggunakan tes pada akhir siklus I, II, dan III, sedangkan data hasil keaktifan belajar diperoleh dengan lembar observasi yang diisi pada setiap pertemuan. Menurut model Kemmis, setiap siklus terdiri dari 4 tahap yaitu: (1) perencanaan (planning); (2) tindakan/pelaksanaan (acting); (3) pengamatan (observing); (4) refleksi (reflecting) (Sukardi, 2014).

Instrumen tes kemampuan pemecahan masalah terdiri dari 4 soal berbentuk uraian. Tes tersebut sebelumnya telah divalidasi oleh 2 orang dosen pendidikan matematika dan 1 orang guru matematika yang kemudian diberikan kepada siswa sebagai tes disetiap akhir siklus. Untuk lembar observasi keaktifan belajar diisi pada setiap pertemuan oleh peneliti dan guru, dimana lembar tersebut memuat indikator perilaku siswa saat mengikuti pembelajaran. Data yang diperoleh kemudian dianalisis secara kuantitatif untuk setiap siklusnya. Data kemampuan pemecahan masalah matematika siswa dianalisis dengan menentukan rata-rata nilai kemampuan pemecahan masalah. Sedangkan untuk data keaktifan belajar siswa dianalisis dengan menentukan persentase skor keaktifan belajar. Berikut ini disajikan pada Tabel 3 yaitu kriteria penggolongan persentase skor keaktifan belajar siswa (Candiasa, 2010).

Tabel 3. Kriteria Penggolongan Keaktifan Belajar Siswa

\begin{tabular}{cc}
\hline Rentangan Persentase Skor $(\%)$ & Kriteria \\
\hline$A \geq 80$ & Sangat Baik \\
$60 \leq A<80$ & Baik \\
$40 \leq A<60$ & Cukup \\
$20 \leq A<40$ & Kurang \\
$A<20$ & Sangat Kurang \\
\hline
\end{tabular}

Tabel 3 di atas menjelaskan mengenai kriteria penggolongan keaktifan belajar siswa dengan rentangan persentase skornya dibagi menjadi 5 kriteria, dari $A$ $<20$ yaitu sangat kurang dan sampai dengan $A \geq 80$ yaitu sangat baik.

Indikator keberhasilan dari penelitian ini adalah (1) nilai kemampuan pemecahan masalah $\geq 70$, meningkat dari siklus ke siklus, dan persentase ketuntasan belajar klasikal siswa mencapai 70\% dari total keseluruhan siswa; (2) rata-rata skor keaktifan belajar siswa minimal berada pada kategori baik. 


\section{Hasil dan Pembahasan}

Data yang diperoleh dari penelitian ini merupakan data dari proses pembelajaran yang dilaksanakan dari siklus I-III. Berikut ini diuraikan kegiatan pembelajaran tiap siklusnya.

\section{Deskripsi hasil pelaksanaan tindakan pada siklus I}

Pada kegiatan pembelajaran siklus I, peneliti menerapkan empat langkah dalam PTK yaitu yang pertama tahap perencanaan. Pada tahap perencanaan tindakan (planning) pada siklus I adalah kegiatan berupa menyusun rencana yang akan dilaksanakan, berupa RPP, LKS, lembar observasi keaktifan belajar, dan soal tes siklus I. Hal-hal yang disiapkan pada saat perencanaan sudah disesuaikan dengan temuan masalah awal dan refleksi pada setiap siklusnya. Berikut ini uraian dari kegiatan pembelajaran selama proses penelitian.

Pada pelaksanaan tindakan (acting), yaitu melaksanakan kegiatan pembelajaran dengan menerapkan langkah-langkah model pembelajaran MEA. Pada siklus I ini dilakukan sebanyak tiga kali pertemuan. Pertemuan pertama, kedua, dan ketiga pada siklus I. Kegiatan pembelajaran diawali kegiatan pembukaan ( \pm 15 menit), guru mengarahkan siswa untuk mengucapkan salam, kemudian dilanjutkan dengan mengecek kehadiran siswa, dan memberikan apersepsi untuk materi pada pertemuan tersebut. Pada kegiatan inti pembelajaran, siswa menerapkan langkah-langkah model pembelajaran MEA dalam menyelesaikan permasalahan pada LKS yang diberikan oleh guru. Siswa diminta untuk duduk dengan kelompoknya masing-masing yang terdiri dari 4-5 orang. Kelompok tersebut sudah dibagi secara acak dan heterogen oleh guru. Pada tahap (1) menyajikan materi dengan pendekatan pemecahan masalah berbasis heuristic, siswa dimotivasi dalam menyelesaikan masalah dengan penyajian soal berupa masalah dalam kehidupan sehari-hari. Dengan menyajikan masalah yang berbasis heuristik, memudahkan siswa dalam menerapkan langkah-langkah pemecahan masalah pada soal yang diberikan. Pada tahap (2) mengelaborasi menjadi subsub masalah yang lebih sederhana, siswa diminta untuk mampu dalam menemukan informasi apa saja yang terkandung dalam soal, seperti apa yang diketahui dan yang ditanyakan. Selanjutnya, siswa diminta untuk mengelaborasi masalah tersebut menjadi dua sub masalah yang lebih sederhana. Pada tahap (3) mengidentifikasi perbedaan, siswa masih merasa kesulitan dalam hal ini karena siswa yang tidak paham konsep materi akan kebingungan untuk memilih mana sub masalah yang akan lebih dulu diselesaikan dan yang tidak. Guru meminta siswa untuk membaca kembali permasalahan dengan baik, kemudian siswa diminta untuk menuliskan 
informasi yang mereka peroleh dalam soal pada LKS. Pada tahap (4) menyusun sub-sub masalah yang sudah diidentifikasi sehingga menjadi koneksivitas. Dalam hal ini, siswa diminta untuk berlatih dalam menyusun sub-sub masalah tersebut akan memiliki keterkaitan dari segi konsep materi dan penyelesaiannya. Pada tahap (5) pilih strategi solusi, tahap terakhir inilah sebagai tahap yang harus dikuasai dan dipahami siswa dengan baik. Siswa bersama anggota kelompoknya diminta untuk menentukan strategi solusi yang paling efektif untuk menyelesaikan masalah yang disajikan. Tetapi masih banyak dari siswa yang merasa kesulitan karena kebanyakan siswa masih ragu atas jawabannya sendiri dan melihat hasil pekerjaan temannya. Dari hal tersebut timbulah kegaduhan didalam kelas. Semestinya dalam hal ini, siswa sendiri yang harus mengkontruksi dan menentukan sesuai konsep dalam setiap permasalahan.

Dalam hal ini, peran guru cukup dominan saat kegiatan diskusi berlangsung, karena siswa masih cenderung belum terbiasa berdiskusi dengan anggota kelompoknya. Diskusi adalah salah satu pendekatan yang mampu meningkatkan keterlibatan secara kognitif maupun memotivasi siswa (Lachner, Weinhuber, \& Nückles, 2019). Saat siswa mediskusikan permasalahan di LKS, siswa cenderung masih bingung saat menerapkan sintaks dari model pembelajaran MEA yang dirasa masih sangat baru untuk dipahami. Pemberian LKS tersebut akan menjadi salah satu bentuk pemberian scaffolding secara konseptual dan prosedural (Phumeechanya \& Wannapiroon, $\underline{2014})$.

Kemudian pada tahapan selanjutnya yaitu tahap pengamatan (observing). Peneliti bersama guru akan mengamati aktivitas siswa selama pembelajaran dan pengukuran hasil belajar siswa melalui tes siklus I. Selama proses diskusi, kebanyakan siswa masih cenderung pasif, terdapat juga yang belum berani untuk berpendapat didepan guru dan teman-temannya. Pada saat ini, siswa diharapkan agar lebih aktif maupun membantu temannya dalam memahami konsep materi (Shepherd \& Van de Sande, 2014) sehingga dengan begitu siswa menjadi lebih termotivasi. Setelah selesai berdiskusi, guru meminta salah satu perwakilan kelompok untuk membahas hasil diskusi didepan kelas. Terlihat siswa masih cenderung malu-malu untuk berbicara didepan kelas. Hal ini perlu untuk ditingkatkan, sehingga tugas guru dan peneliti harus mampu meningkatkan kepercayaan diri siswa sehingga siswa akan menjadi lebih aktif dalam proses pembelajaran. Pada pertemuan terakhir pada siklus I adalah pemberian tes kemampuan pemecahan masalah kepada seluruh siswa sebagai evaluasi proses selama pemberian tindakan pada siklus I. Berikut ini hasil jawaban salah satu siswa disiklus I pada Gambar 2. 


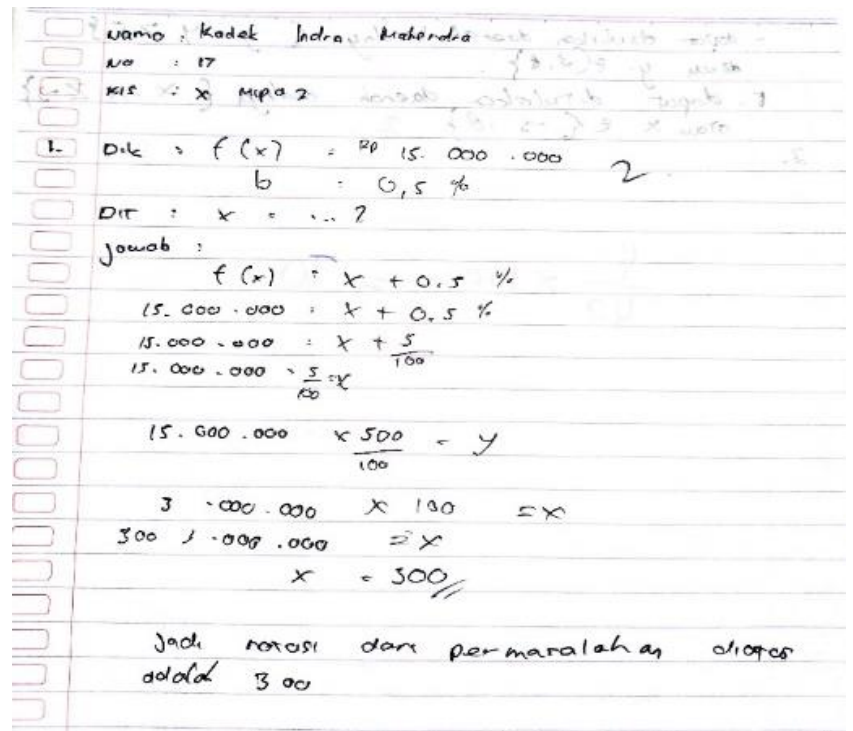

Gambar 2. Hasil Jawaban Siswa pada Tes Siklus I

Gambar 2 menunjukkan bahwa siswa belum mampu dalam memahami masalah, merencanakan, dan melaksanakan pemecahan masalah dengan benar. Terlihat dari cara siswa menuliskan apa yang ditanyakan pada soal, siswa keliru sehingga mengalami kesalahan dalam menjawabnya. Terkait hasil tersebut, guru dan peneliti melakukan tahapan terakhir yaitu tahap refleksi (reflecting). Kemudian berdiskusi untuk merancang perbaikan berupa refleksi yang akan diterapkan pada pembelajaran disiklus II, dimana salah satu refleksinya adalah memotivasi siswanya agar tidak hanya mengandalkan teman saat menjawab LKS sehingga berdampak pada hasil evaluasi akhir siklus dan meningkatkan keaktifan saat bertanya kepada guru maupun mengemukakan pendapat.

\section{Deskripsi hasil pelaksanaan tindakan pada siklus II}

Pada siklus II ini, guru melaksanakan kegiatan pembelajaran dengan menerapkan model pembelajaran MEA yang langkah-langkahnya sama seperti pada siklus I. Tahap perencanaan tindakan (planning) pada siklus II adalah dengan menyiapkan RPP, LKS, dan soal tes siklus II. Kemudian pada tahap pelaksanaan tindakan (acting), diawal proses pembelajaran dilaksanakan sama seperti pada siklus I. Saat dibagikan LKS, seluruh siswa sudah langsung cepat tanggap untuk memecahkan soal-soalnya dengan menerapkan langkah-langkah model pembelajaran MEA. Siswa sudah mampu memahami masalah dengan menuliskan apa yang diketahui dan ditanyakan pada soal, kemudian siswa dapat merencanakan masalah dan melaksaakan pemecahan masalah dengan mengelaborasi masalah menjadi 
sub-sub masalah yang lebih sederhana. Kemudian seperti biasanya, setelah selesai berdiskusi beberapa perwakilan kelompok diminta maju kedepan untuk membahas hasil diskusi mereka masing-masing.

Pada tahapan inilah guru melaksanakan tahap pengamatan (observing) guru membimbing siswa dalam mengecek apakah strategi solusi yang mereka pilih sudah sesuai dengan konsep materi dari permasalahannya. Guru meminta seluruh siswa yang masih kebingungan untuk lebih memahami konsep dari setiap matei yang dibahas sehingga saat memecahkan permasalahan, siswa dapat memilih strategi solusi yang benar. Menurut Reamer, Ivy, Vila-Parrish, \& Young (2015) bahwa di Amerika pun masih terdapat siswa yang mengalami kegagalan dalam memahami konsep dalam menyelesaikan masalah. Pada siklus II, keaktifan siswa saat proses pembelajaran dikelas sudah mengalami peningkatan. Misalnya, siswa yang sering ribut menjadi lebih diam dan mau mengerti kondisi. Siswa-siswa yang awalnya tidak mau mengemukakan pendapat, pada siklus II ini mereka sudah terlihat aktif dalam bertanya maupun menjawab pertanyaan. Berikut ini hasil jawaban salah satu siswa disiklus II pada Gambar 3.

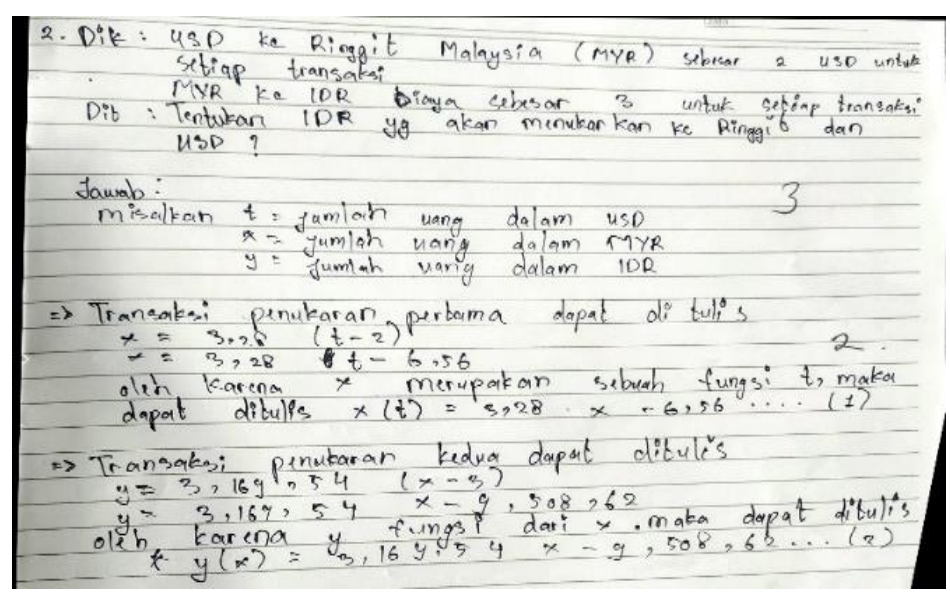

Gambar 3. Hasil Jawaban Siswa pada Tes Siklus II

Gambar 3 menunjukkan mulai ada perubahan siswa dalam memecahkan masalah. Siswa sudah dapat memahami masalah dan merencanakan pemecahan masalah dengan baik tetapi dalam proses penyelesainnya siswa mengalami kesulitan dalam menerapkan konsep materi komposisi fungsi ke soal tersebut. Bertolak pada temuan pada saat pembelajaran disiklus II, guru dan peneliti melaksanakan tahap refleksi (reflecting) dengan merancang perbaikan yang akan dijadikan refleksi pada saat pemberian tindakan disklus III dengan harapan agar seluruh siswa sudah mampu mencapai kriteria dalam indikator keberhasilan 


\section{Deskripsi hasil pelaksanaan tindakan pada siklus III}

Pada siklus III, kegiatan pembelajaran yang dilaksanakan sama dengan siklus I dan II dengan menerapkan model pembelajaran MEA. Pada tahap pelaksanaan tindakan (acting), terlihat seluruh siswa sudah terbiasa dengan model pembelajaran yang diberikan, keaktifan siswa pun semakin terlihat. Ketika dibagikan LKS, siswa sudah paham bagaimana langkah-langkah sesuai model pembelajaran untuk menyelesaikan permasalahan. Yang biasanya kelas mengalami kegaduhan, kini sudah nampak sepi saat proses diskusi berlangsung. Beberapa siswa yang masih ada kesulitan tidak langsung bertanya kepada guru melainkan memecahkannya bersama anggota kelompoknya. Siswa sudah mampu menerapkan langkah-langkah dari model MEA dengan baik dan kondusif. Guru dan peneliti juga melakukan tahap pengamatan (observing) untuk melihat bagaimana perilaku siswa selama mengikuti proses pembelajaran di siklus II ini. Diakhir pertemuan seperti biasa, seluruh siswa diberikan tes akhir siklus III. Berikut ini hasil jawaban salah satu siswa disiklus III pada Gambar 4.

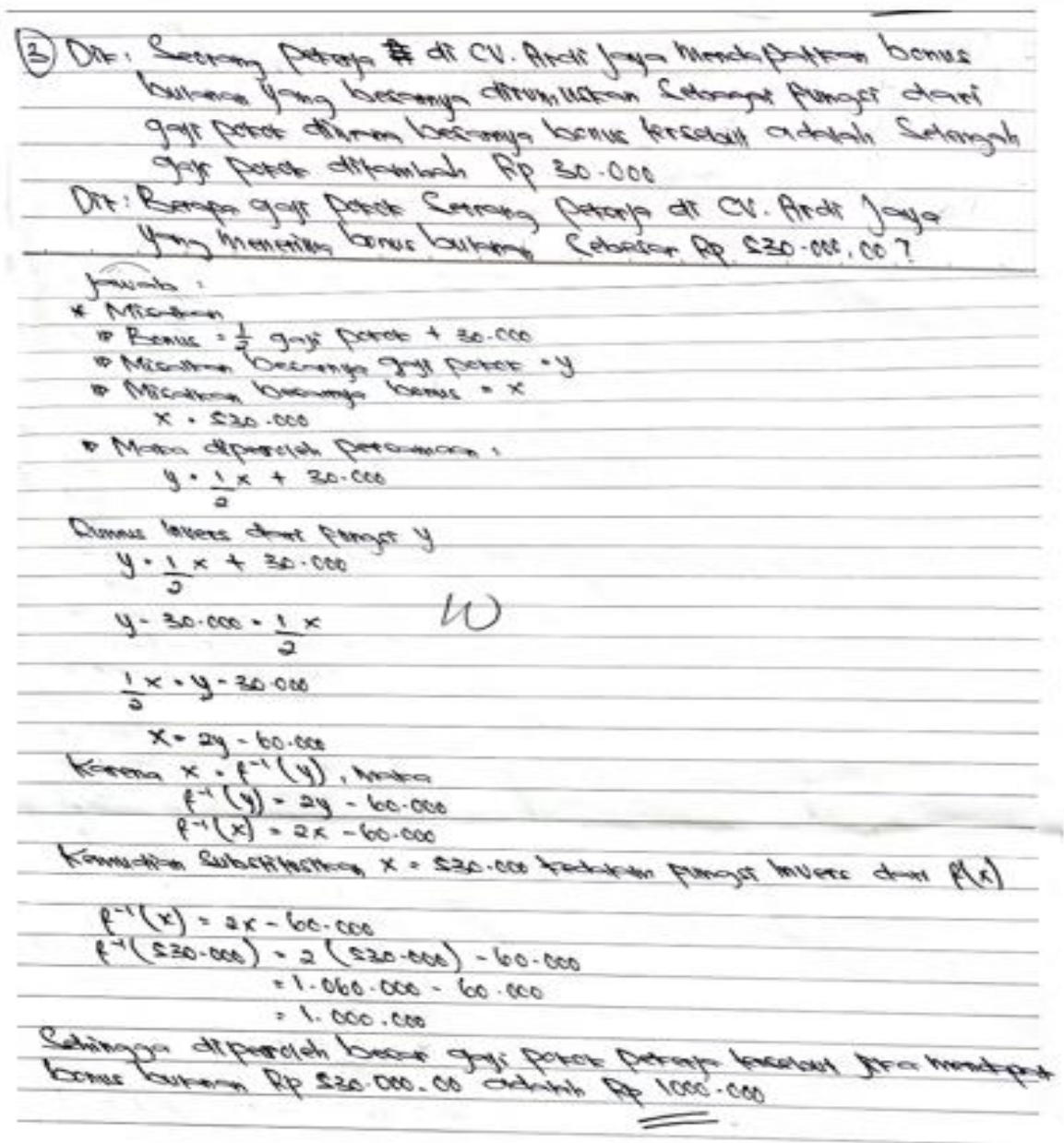

Gambar 4. Hasil Jawaban Siswa pada Tes Siklus III 
Gambar 4 menunjukkan bahwa pada siklus III sudah tampak jelas pemecahan masalahnya. Siswa sudah mampu menerapkan setiap indikator, yaitu memahami masalah dengan menuliskan apa yang diketahui dan ditanya, kemudian menuliskan rencana pemecahan masalah, selanjutnya siswa menerapkan dan melaksanakannya sesuai konsep materi invers fungsi dan memeriksa kembali secara benar sesuai proses.

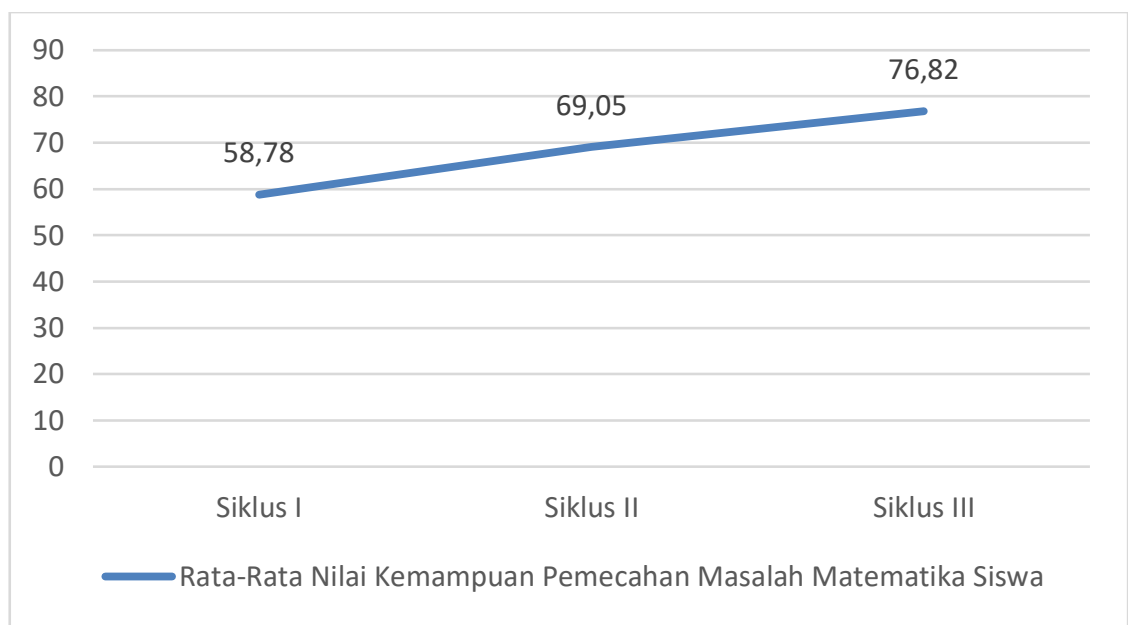

Gambar 5. Rata-rata nilai kemampuan pemecahan masalah matematika Siswa

Gambar 5 menunjukkan bahwa rata-rata kemampuan pemecahan masalah pada hasil tes mengalami peningkatan, mulai dari refleksi awal, siklus I, siklus II, dan siklus III. Sedangkan persentase skor keaktifan belajar siswa disajikan dalam bentuk diagram garis pada Gambar 6 .

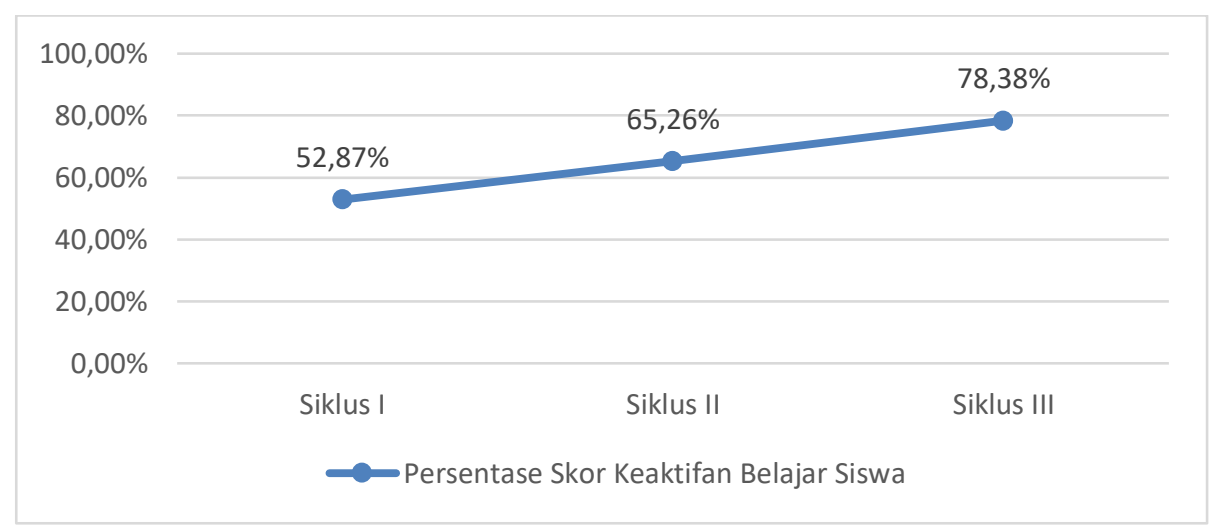

Gambar 6. Persentase skor keaktifan belajar siswa

Gambar 6 menunjukkan bahwa terjadi peningkatan juga pada persentase skor keaktifan belajar dari siklus I sampai dengan siklus III. Hal tersebut juga didukung dengan adanya peningkatan aktivitas seluruh siswa dikelas. 
Berikut ini persentase ketuntasan belajar klasikal siswa dalam bentuk diagram garis pada Gambar 7.

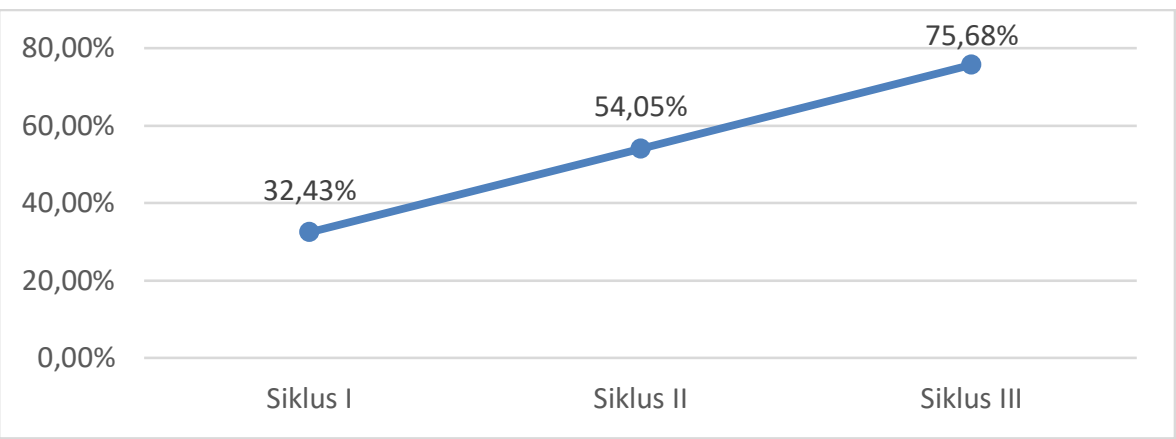

Gambar 7. Persentase Ketuntasan Belajar Klasikal Siswa

Gambar 7 menunjukkan bahwa adanya peningkatan ketuntasan belajar klasikal siswa pada kemampuan pemecahan masalah matematika. Hal ini sejalan dengan hasil penelitian yang dilaksanakan oleh Saraswati, Kristin, \& Anugraheni (2018); Citoresmi \& Nurhayati (2017) yang menyatakan bahwa model pembelajaran MEA dapat meningkatkan kemampuan pemecahan masalah matematika siswa.

Secara umum pada pelaksanaan tindakan siklus I, perubahan cara belajar siswa yang awalnya lebih didominasi guru tetapi sekarang lebih menuntut keaktifan siswa sehingga siswa belum terbiasa dengan model pembelajaran yang diterapkan. Kebanyakan siswa memanfaatkan diskusi kelompok dengan mengobrol bersama teman lainnya dan beberapa siswa masih mengandalkan teman kelompoknya untuk memecahkan permasalahan pada LKS. Seharusnya, dengan berdiskusi siswa akan lebih mudah dalam berinteraksi dengan siswa lain, terutama dalam mendiskusikan bagaimana memecahkan soal-soal yang diberikan. Hal ini sejalan dengan pendapat dari Suherman (2003), memilih untuk berdiskusi kelompok dalam kegiatan belajar akan berdampak baik bagi siswa sehingga memudahkannya dalam bertukar ide yang digunakan dalam memecahkan permasalahan. Pada tahap menjawab soal hampir seluruh siswa masih belum terbiasa dengan penerapan model pembelajaran MEA, dan siswa masih terlihat kurang aktif saat berdiskusi maupun saat berpendapat. Sehingga pelaksanaan tindakan pada siklus I masih kurang optimal. Kemudian diperoleh hasil tes dari 37 orang siswa kelas $X$ MIPA 2 SMAN 2 Singaraja. Persentase banyaknya siswa yang nilainya berada pada kriteria ketuntasan sebesar 32,43\% (12 orang), sedangkan persentase banyaknya siswa yang nilainya belum memenuhi kriteria ketuntasan sebesar $67,57 \%$ (25 orang). Sementara itu, rata-rata nilai kemampuan pemecahan masalah matematika siswa pada siklus I adalah 58,78 
dengan kategori belum tuntas dan persentase skor keaktifan belajar siswa sebesar 52,87\% dengan kategori cukup.

Pada pelaksanaan tindakan siklus II, terlihat adanya peningkatan kemampuan pemecahan masalah matematika bagi siswa dari siklus I ke siklus II. Siswa nampak sudah mulai mampu dalam memecahkan masalah dengan menerapkan langkah-langkah dari model pembelajaran, walaupun tidak seluruh siswa tetapi siswa sudah mulai berusaha berdiskusi dan mengerjakan LKS dengan tekun. Sehingga hal tersebut berdampak pada kekaktifan belajar siswa. Siswa seharusnya sudah memahami konsep materinya dengan baik agar mampu merencanakan, melaksanakan, dan memilih strategi solusi pada saat memecahkan masalah dengan benar. Kemudian diperoleh hasil tes kemampuan pemecahan masalah matematika siswa tertinggi adalah 90, sedangkan nilai terendahnya adalah 45 . Persentase banyaknya siswa yang nilainya berada pada kriteria ketuntasan sebesar 54,05\% (20 orang), sedangkan persentase banyaknya siswa yang nilainya belum memenuhi kriteria ketuntasan sebesar 45,95\% (17 orang). Sementara itu, rata-rata nilai kemampuan pemecahan masalah matematika siswa pada siklus II adalah 69,05 dengan kategori belum tuntas dan persentase skor keaktifan belajar siswa sebesar $65,26 \%$ dengan kategori baik.

Pada pelaksanaan tindakan siklus III, sudah tidak ada lagi kendala yang berarti. Kemampuan pemecahan masalah dan keaktifan belajar siswa sudah mengalami peningkatan yang signifikan. Selain itu, menurut Sudjana (2005) keaktifan belajar siswa menjadi lebih lebih terlibat saat proses pemecahan masalah. Sehingga diperoleh hasil tes kemampuan pemecahan masalah matematika siswa tertinggi adalah 100, sedangkan nilai terendahnya adalah 52,5 . Persentase banyaknya siswa yang nilainya berada pada kriteria ketuntasan sebesar 75,68\% (28 orang), sedangkan persentase banyaknya siswa yang nilainya belum memenuhi kriteria ketuntasan sebesar 24,32\% (9 orang). Sementara itu, rata-rata nilai kemampuan pemecahan masalah matematika siswa pada siklus III adalah 76,82 dengan kategori tuntas dan persentase skor keaktifan belajar siswa sebesar 78,38\% dengan kategori baik. Dengan demikian, hasil dari siklus III telah mencapai seluruh indikator keberhasilan pada metode penelitian.

Hal ini sejalan dengan hasil penelitian yang dilaksanakan oleh Rama (2016) bahwa penerapan model pembelajaran MEA mampu meningkatkan kemampuan pemecahan masalah matematis siswa kelas VIII SMP. Karena terjadi peningkatan yang rata-rata nilai kemampuan pemecahan masalah matematis siswa tiap siklusnya, yang dapat dinyatakan bahwa penelitian ini 
sudah memenuhi indikator keberhasilan. Juanda \& Ikhsan (2014) bahwa pembelajaran dengan model MEA terhadap kemampuan pemecahan masalah matematis siswa mampu memberikan pengaruh positif. Karena terdapat interaksi antara faktor model pembelajaran dengan level kemampuan siswa.

\section{Simpulan}

Berdasarkan hasil penelitian tindakan kelas ini, dapat disimpulkan bahwa penerapan model pembelajaran MEA dapat dikatakan tepat untuk meningkatkan kemampuan pemecahan masalah dan keaktifan belajar siswa kelas X MIPA 2 SMA Negeri 2 Singaraja pada materi fungsi. Hal tersebut karena adanya peningkatan dari rata-rata nilai maupun ketuntasan belajar dari siswa dari siklus I-III dengan menggunakan model pembelajaran MEA. Model pembelajaran MEA juga telah mampu meningkatkan aktivitas siswa dari segi keaktifan belajar yang mencapau kategori baik. Karena persentase siswa yang aktif lebih tinggi daripada siswa yang pasif. Guru dapat menerapkan model pembelajaran ini untuk membantu mengatasi masalah berupa rendahnya kemampuan pemecahan masalah dan keaktifan belajar bagi siswa dengan cara memotivasi siswa terlebih dahulu.

\section{Daftar Pustaka}

Candiasa, I. M. (2010). Statistik Univariat dan Bivariat Disertai Aplikasi SPSS. Singaraja: Unit Penerbitan Universitas Pendidikan Ganesha Singaraja.

Chaudhry, N. G., \& Rasool, G. (2012). A Case Study on Improving Problem Solving Skills of Undergraduate Computer Science Students. World Applied Sciences Journal, 20(1), 34-39.

Chavez, J. A. (2007). Enlivening problems with heuristics through learning activities and problem solving (LAPS). Learning Science and Mathematics, SEAMEO RECSAM, 2, 1-18.

Citoresmi, N., \& Nurhayati. (2017). Penerapan Model Pembelajaran Means-Ends Analysis Untuk Meningkatkan Kemampuan Pemecahan Masalah Matematis Siswa. Jurnal Pendidikan Matematika Indonesia, 2(1), 13-18.

Csapó, B., \& Funke, J. (2017). The nature of problem solving. Using research to inspire 21st century learning. Educational Research and Innovation, 1(1), 1-34.

Harkness, S. S., \& Noblitt, B. (2017). Playing the believing game: Enhancing productive discourse and mathematical understanding. Journal of Mathematical Behavior, 45, 63-77.

Huda, M. (2013). Model-Model Pengajaran dan Pembelajaran. Yogyakarta: Pustaka Belajar.

Juanda, J. R. \& Ikhsan, M. (2014). Peningkatan Kemampuan Pemecahan Masalah dan Komunikasi Matematis Siswa SMP melalui Model Pembelajaran Means-ends Analysis. Jurnal Matematika Kreatif Inovatif, 5(2), 108-110.

Lachner, A., Weinhuber, M., \& Nückles, M. (2019). To Teach or Not to Teach The Conceptual Structure of Mathematics? Teachers Undervalue The Potential of Principle-Oriented Explanations. Contemporary Educational Psychology, 58(March), 175-185.

Laterell, C. M. (2013). What Is Problem-solving Ability? LATM Journal, 1(1), 1-12.

Malalina, M., \& Kesumawati, N. (2014). Pengembangan Bahan Ajar Interaktif Berbasis Komputer Pokok Bahasan Lingkaran Untuk Kelas VIII Sekolah Menengah Pertama. Jurnal Pendidikan Matematika Indonesia, 8(1), 55-70.

Özreçberoğlu, N., \& Çağanağa, Ç. K. (2018). Making It Count: Strategies for Improving 
Problem-Solving Skills in Mathematics for Students and Teachers' Classroom Management. Eurasia Journal of Mathematics, Science and Technology Education, 14(4), 12531261.

Phumeechanya, N., \& Wannapiroon, P. (2014). Design of Problem-based with Scaffolding Learning Activities in Ubiquitous Learning Environment to Develop Problem-solving Skills. Procedia - Social and Behavioral Sciences, 116, 4803-4808.

Polya, G. (1957). How to Solve it. Princenton University Press.

Rahmawati, F. (2013). Pengaruh Pendekatan Pendidikan Realistik Matematika dalam Meningkatkan Kemampuan Komunikasi Matematis Siswa Sekolah Dasar. Prosiding SEMIRATA 2013, 1(1), 225-238.

Rama, Y. A. (2016). Meningkatkan Kemampuan Pemecahan Masalah Matematis Siswa Kelas VIII-F SMPN 14 Banjarmasin Melalui Model Pembelajaran Means End Analysis (MEA). Edu-Mat: Jurnal Pendidikan Matematika, 4(2), 1-9.

Reamer, A. C., Ivy, J. S., Vila-Parrish, A. R., \& Young, R. E. (2015). Understanding the evolution of mathematics performance in primary education and the implications for STEM learning: A Markovian approach. Computers in Human Behavior, 47, 4-17.

Saraswati, D., Kristin, F., \& Anugraheni, I. (2018). Peningkatan Kemampuan Pemecahan Masalah Matematika Menggunakan Model Means Ends Analysis (MEA) Bagi Siswa Kelas 5 SD Negeri Sumogawe 02. Jurnal Pendidikan Dasar PerKhasa, 4(1), 1-12.

Shepherd, M. D., \& Van de Sande, C. C. (2014). Reading Mathematics for Understanding-From Novice to Expert. Journal of Mathematical Behavior, 35, 74-86.

Sinaga, N. (2018). Penerapan Pembelajaran Matematika Realistik untuk Meningkatkan Kemampuan Pemahaman Matematis Siswa Pada Materi Bentuk Aljabar di Kelas VII SMP. Cartesius: Jurnal Pendidikan Matematika, 1(1), 25-35.

Sudjana, N. (2005). Dasar-dasar Proses Belajar Mengajar. Bandung: Sinar Baru Algensindo.

Suherman, E., dkk. (2003). Strategi Pembelajaran Matematika Kontemporer. Technical Cooperation Project for Development of Science and Mathematics teaching for Primary and Secondary Education in Indonesia. Bandung: Jurusan Pendidikan Matematika FMIPA UPI.

Suherman, E. (2008). Belajar dan Pembelajaran Matematika. Bandung.

Sukardi. (2014). Metodologi Penelitian Pendidikan. Yogyakarta: Bumi Aksara.

Syah, M. (2008). Psikologi Pendidikan. Bandung: Remaja Rosdakarya.

Usman, M. U. (2009). Menjadi Guru Profesional. Bandung: Remaja Rosdakarya.

Varma, S., \& Schwartz, D. L. (2011). The Mental Representation of Integers: An Abstract-ToConcrete Shift in The Understanding of Mathematical Concepts. Cognition, 121(3), 363385. 